\title{
A religião e os encarcerados em transe, êxtase e possessão
}

\section{Religion and the incarcerated, tried and possessed}

\section{Antônio César Martins Lopes*}

Recebido em: 10/09/2019. Aceito em: 08/11/2019.

Resumo: Este artigo propõe analisar, pela epistemologia do transe, êxtase e possessão a religião dos excluídos na contemporaneidade, sua relação paradigmática com a fé enquanto força abstrata, quiçá, alienação a moldar a consciência da população enclausurada no cárcere dos tempos atuais. Em relação aos excluídos, referenciados por diferentes autores e matrizes ideológicas, tratar sobre o status físico e espiritual do sujeito apartado do ser social, o que conclama conceitos relacionados aos direitos, emancipação, libertação e indaga sobre a questão penal da restrição das liberdades.

Palavras-chave: Contemporaneidade. Religião. Transe. Presídio. Possessão.

Abstract: This article proposes to analyze, through the epistemology of trance, ecstasy and possession, the religion of the excluded in contemporary times, its paradigmatic relationship with faith as an abstract force, perhaps alienation, shaping the consciousness of the population locked in the prison of the present times. Regarding the excluded, referenced by different authors and ideological matrices, treat about the physical and spiritual status of the subject separated from the social being, which calls for concepts related to rights, emancipation, liberation and inquires about the criminal question of the restriction of freedoms.

Keywords: Contemporaneity. Religion. Trance. Presidio. Salvation.

\section{Introdução}

Este artigo propõe analisar pela epistemologia do transe, êxtase e possessão, a religião e os excluídos na contemporaneidade ${ }^{1}$ numa rela-

* Doutorando em Ciências da Religião (Pontifícia Universidade Católica de Goiás). Mestre em Serviço Social, (Pontifícia Universidade Católica de Goiás, Goiânia, 2016). Mestrando em Direitos Humanos (Universidade Federal de Goiás, Goiânia). Bacharel em Serviço Social (Pontifícia Universidade Católica de Goiás, Goiânia, 2013).

E-mail: blackpearlopes@yahoo.com

1 Nesse artigo a categoria excluídos remonta aos sujeitos em situação de restrição da liberdade, instalados na prisão, recorrência histórica da luta de classes em torno do 
ção paradigmática com a fé enquanto força abstrata, quiçá, alienação a moldar a consciência da população enclausurada. Estrutura-se em conceitos que relacionam ao cárcere dos tempos atuais, aos excluídos, com foco em diferenciados autores e matrizes ideológicas, a inferir sobre o status físico e espiritual do ser social. Traz à tona da discussão conceitos relacionados ao direito, emancipação e libertação, indaga sobre a questão penal da restrição das liberdades sob o espectro do transe, êxtase e possessão na arena da marginalização ou escravidão moderna, retratada na prisão, espaço de iniquidades quando e aonde os leigos e voluntariados religiosos, representados nas mais variadas correntes ideológicas da sociedade organizada - trabalham e manipulam a histeria coletiva. A instituição panóptica do cárcere caracteriza a situação de desespero do sujeito em restrição da liberdade, sobressai-se à loucura entre as grades pelo viés do fenômeno da crença a conclamar, em êxtase, a libertação sob os gritos aos céus e à Terra com a força e voz da religião que ameniza e extrapola a magia ou histeria coletiva ali instalados. Expressão social, umbilicalmente atrelada ao campo jurídico, este fenômeno extrapola os limites dos muros institucionais a cercear e excluir as liberdades, dignidades, corpos em possessão. A crença humana, hipnotizada, sob a guarda do poder de fato, trama com as regras jurídico-penais do Estado o teatro dos oprimidos, caracterizados nesse artigo como os excluídos da contemporaneidade.

Assim, no tópico 1.1, abordar-se-á a prisão e o transe. O tópico posterior, 1.2, trata-se de discutir a exclusão como possessão. $\mathrm{O}$ artigo chegará ao fim com o tópico 1.3, onde são apresentados os sintomas do êxtase na Contemporaneidade, trespassada pela cultura e os sistemas simbólicos, a religião e costumes os quais, desde a Antiguidade, dão gênese à relação paradigmática prisão e fé. A luta pela sobrevivência estreita essa relação material, filosófica, permeada pela existência concreta e a crença abstrata - alicerce da alma ou consciência a resistir à alienação capitalista. Com relação à expressão social da exclusão, dialética, o diálogo se dá por conceitos tais como contemporaneidade, religião, transe, presídio e salvação.

controle dos meios de produção e manutenção dos privilégios de classe. Para Marx e Engels, em o Manifesto do Partido Comunista (1848): "A história de toda a sociedade até hoje é a história da luta de classes" (1998:1). Para além da posse dos meios de produção, as classes dominantes controlam e dominam também os aparelhos políticos e ideológicos, alimentando e difundindo as ideias, doutrinas e ideologias que lhes são favoráveis. 


\subsection{A instituição prisão e a libertação pelo transe da fé}

O termo prisão designa o ato de prender ou capturar alguém que cometeu um crime, fazer com que perca sua liberdade como forma de pagar pelo ato, a partir da sua exclusão social. Processo contraditório numa coletividade imersa em sua historicidade a qual revela, segundo Onofre (2014, p. 20) uma necessidade primordial:

[...] construir uma sociedade onde os excluidos tenham espaço, onde possam fazer-se ouvir, onde possam gozar do direito a uma educação radicalmente democrática. Não existe qualidade com dualização social. Qualidade para poucos não é qualidade, é privilégio.

E essa exclusão tem gênese em fatores sociais que exercem força sobre o humano alojado na arena da escravidão de mercado aonde: " $\mathrm{O}$ dispositivo panóptico ${ }^{2}$ organiza unidades espaciais que permitem ver sem parar e reconhecer imediatamente" (FOUCAULT, 2010, p. 194). Este que é um sistema de vigilância criado pelo filósofo e jurista inglês Jeremy Bentham, em 1785, erguido a muros, vigilância, punição e penalização do aprisionado. Bentham estudou "racionalmente", em suas próprias palavras, o sistema penitenciário e criou, então, um projeto de prisão circular, quando um observador central poderia ver todos os locais onde houvesse presos.

A cadeia, prisão ou sistema panóptico revela uma carga de originalidade na expressão falada, contada e escrita dos apenados, real, de quem se encontrava, ou, habitou por detrás das grades prisionais, destinadas pelo sistema a trancafiar vidas fragmentadas a corpos e almas violentados na exclusão.

A vivência prisional me deu a oportunidade de conhecer de perto o sofrimento e o conflito entre os homens. Conhecer de perto pessoas que vivenciam a cada instante os limites da violência, da vida e da morte. Eu me preocupo sempre em não seguir a rota comum, aproveitando o impacto das narrativas como ganchos para passar minhas mensagens. Aqui o universo se encaixa no corriqueiro, procurando sempre descobrir, surpreender, flagrar, compreender o dia a dia do marginal, com suas contradições e sofrimentos. (RAMOS, 2002, p. 11)

2 Pan-óptico: termo utilizado para designar uma penitenciária ideal, que permite a um único vigilante observar todos os prisioneiros, sem que estes possam saber se estão ou não sendo vigiados. O medo e o receio de não saberem se estão a ser espreitados leva-os a adotar a comportamento desejado pelo vigilante. 
A prisão é palavra com origem no latim vulgar prensione, derivado do latim clássico e popular prehensione - ato de prender, em tempos pós-modernos, determinado pela jurisdição que julga, condena e encarcera trabalhadores excluídos do processo de produção em massa do capitalismo concorrencial. A Bíblia de Estudos Conselheira (2019, p. 1939), tecendo comentário acerca da Carta do Apóstolo Paulo ao escravo Onésimo, quando ambos estavam na prisão, registra:

A busca pela liberdade é inerente ao ser humano. Ao longo de milênios as mais variadas sociedades construíram diversos arranjos sobre o exercício do poder no grupo. Sempre encontramos estruturas de poder, umas mais fechadas, exclusivistas e tirânicas, outras mais abertas e incluidoras, com maior mobilidade.

O conceito prisão subentende ensinar, dar aula, significado extraído do latim e assimilado pelas culturas anglo-portuguesas. De acordo com o Dicionário Houaiss (2008, p. 604): “Captura; aprisionamento; qualidade de quem está preso; cativeiro". Por extensão, é sinônimo da pena em que há privação completa da liberdade. Betto (2008, p. 34) assim descreve a prisão: "Distante do mundo dos horários, dos afazeres obrigatórios, dos dias úteis e feriados, das manhãs de sol e das noites de lua, do ruído das ruas e dos jardins floridos".

A prisão institucional trama a relação simbólico-cultural antagônica permeada pela fé, a questão dos Direitos Humanos e Constitucionais, leis que regem a sociedade humana organizada, estruturada por sistemas jurídicos, simbólicos e comportamentais, elementos criativos e função biológica para a religião a permitir as transformações no decorrer da vida humana, incluindo a crença na imortalidade.

O mundo contemporâneo traduz uma coletividade a caminhar na contramão desses valores, trespassado por instâncias de experiência do ser humano, com a realidade circundante, o transe da realidade oposta à Carta de Paulo $(1 \mathrm{Ts} 4,11)$ que relata um tempo em que os valores resumiam a que "seja para vocês uma questão de honra viver em paz, ocupando-se com as coisas que lhes pertencem e trabalhando com as próprias mãos, conforme recomendamos" (FERREIRA; SILVA, 2009, p. 33). O quadro social, religioso e político, trespassado pelos processos da suposta secularização, determina o abandono as crenças religiosas e a busca das formas de crença na racionalidade científica. 
Velha, a prisão é arena moderna que restringe as liberdades, local da loucura generalizada a fomentar novas combinações no estilo de espiritualidade envolto no véu da alta modernidade, quando os nichos de espiritualidade, os mais diversos, produzem combinações, em trânsito, imprecisas de um ponto de vista filosófico-teológico (CARVALHO, 1994, p. 92, apud CAMURÇA, 2016).

O sagrado trafega pelos trilhos da história e alimenta a cultura, habita por entre as grades da prisão, perpetua as tradições, perfila as promessas de salvação, ilumina a moral conservadora. Apresenta duas vertentes, ao tempo em que revela gumes dualistas tais como "o impuro e o puro, a sombra e a luz, o verso e o reverso" (SILVEIRA, 2013, p. 92).

Para alguns, a religião é o pálido reflexo do sagrado selvagem, momento das religiões estruturadas como crenças explicativas do mundo, as quais substituem a sensibilidade mágica. A produção religiosa trama essa racionalidade explicativa - que Ruiz (2004, p. 118) conceitua como "uma simbologia implicante", trespassada pela dimensão simbólica que estrutura os diversos saberes.

Volta e meia, espoca no grito extático dos pentecostais, na gira atrevida das danças afro-brasileiras, no silêncio aveludado das iogas, no caleidoscópio psicodélico new age, nos latinórios tradicionalistas, na cristalina mensagem dos espíritos ou do Espírito Santo, movendo os sapatinhos de fogo ou as correntes de prosperidade (SILVEIRA, 2013, p. 93). Na modernidade, envolta pela era pós, o religioso oscila entre a fala ritual, performática e oracular, além da racionalidade, desencantada e reflexiva.

A religião fornece sentido, é fator de coesão, nomia social, revela a relação direta com as sociedades industriais, trilha o caminho interior que deve abandonar o fundamentalismo das formas religiosas. O sistema capitalista aliena o trabalhador "numa pluralidade de dificuldades a enfrentar uma a uma [...] a formação social [...] O salariado acampou durante muito tempo às margens da sociedade; depois aí se instalou, permanecendo subordinado" (CASTEL, 1998, p. 495) ao modo de produção e reprodução das relações sociais pós-modernas

Na condição de mercadoria, sob as condições incertas da "sociedade salarial moderna" imersa na "ideologia da segurança" (COUTINHO, 2010, p. 73), o sujeito luta pela sobrevivência, à margem das fronteiras da coesão social afastada "do domínio da racionalidade - todas as 
questões colocadas pela ética humanista, pela ontologia materialista e pelo materialismo concreto" (idem). Este o mote do próximo capítulo, a tratar sobre a fé, a partir da crença e determinação histórica do mundo moderno em possessão, envolto no véu da era pós.

\subsection{A exclusão como possessão}

Sob a ótica da fé, crença e história a trama da conjuntura mundial determina a secularização e a exclusão social, objetos desse artigo a recair na pauperização, mazela social pois "a pobreza é um entrave e uma ameaça para essas populações (pobres) como para as áreas mais prósperas" (AMMANN, 1980, p. 30 apud GIDDENS, 2011, p. 130). O que, segundo Silveira (2013. p. 93) caracteriza "o marco identitário normativo-ontológico ainda é importante para muitos indivíduos e grupos em sua busca de âncoras sociais para o sagrado".

Paradigma antropológico legal, religioso e midiático, o sistema panóptico sugere a reflexão sobre o cotidiano esboçado na restrição da liberdade quando o corpo atua no campo de tensão e possessão coletiva da população encarcerada retratada a seres sociais contemporâneos excluídos, antes mesmo de sua prisão. Ali gemem os relegados à margem pela sociedade capitalista que alcança as raias da alta modernidade à luz do silêncio embebido na possessão e fé: "Nesse sentido, todo discurso está ligado a um aparato institucional de sustentação e a mecanismos de controle, delimitação e exclusão" (FOUCAULT, 2010). Em transe, os excluídos e marginalizados convivem com o êxtase retratado na vida alienada atrás das grades.

A instituição panóptica restringe gêneros e almas, arena na qual a fé engendra a conjuntura sociopolítica aonde sobressaem expressões sociais ligadas à violência que caracteriza parte da questão social, dialética, voraz: "A dialética ${ }^{3}$ retrata a relação social político-religiosa expressa no campo da fé, perpassa a arena que estabelece o poder, retrata a estrutura

3 Para o marxismo, dialética é o pensamento e a realidade ao mesmo tempo, ou seja, a realidade é contraditória com o pensamento dialético. O materialismo dialético é concepção filosófica que defende que o ambiente, o organismo e os fenômenos físicos tanto modelam animais irracionais e racionais, sua sociedade e cultura quanto são modelados por eles, ou seja, que a matéria está em uma relação dialética com o psicológico e o social. Disponível em: <https://pt.wikipedia.org/wiki/Materialismo_dial\%C3\%A9tico>. 
das relações sociais ligadas "à manutenção da ordem simbólica articulada em função de manter o sistema político o qual se subverte pela inversão política dessa ordem simbólica" (BOURDIEU, 1974, p. 69).

Por entre alas que abrigam seres desumanizados, a partir do barulho de metal das chaves que fecham, prendem, abrem e libertam pelas portas da prisão, o sopro de vidas açoitadas na restrição da liberdade de destinos, o sistema panóptico ecoa o grito do desespero, silenciado a religião que atenua a possessão ${ }^{4} \mathrm{e}$ transe. Naquele caldeirão das iniquidades a paz e o controle social dependem do êxtase que promove a salvação do homem detido, sujeitado à exclusão prisional.

Dessa forma, a construção da identidade como tarefa empreendida, submersa nos atuais fluxos de mídia e consumo, é um trabalho religioso extenuante, já que as fronteiras entre sociedade, outros grupos religiosos e fenômenos sociais precisam ser recompostas a partir de diversas estratégias de diferenciação, por um lado, e indistinção, por outro (SILVEIRA, 2013, p. 104).

Contaminado por um longo desfile de rituais, mitos e cosmologias de purificação, exorcismo e afastamento; contágio por outro, com um rico cortejo de rituais, mitos e cosmologias do transe, possessão e êxtase, o ambiente da carceragem retrata a exclusão ${ }^{5}$ dos possuídos pela força da mazela social ligada à violência. Sem perguntar por status social, o discurso religioso está associado aos atores sociais que o assumem e o emitem, bem como aos canais de transmissão, validação e legitimação (SILVEIRA, 2013, p. 105).

\subsection{0 êxtase da sobrevivência na contemporaneidade}

A Cultura e os Sistemas Simbólicos bebem da fé e da religião coletivas quando a proposta de inclusão social é regulada por leis, políticas públicas e arquétipos societários. Desigual, a sociedade é caracterizada por inúmeras expressões sociais em transe tais como a exclusão, violência e desigualdade, o que revela a luta pela sobrevivência estreitada

4 Possessão: Possessão ou possessão demoníaca é, de acordo com muitos sistemas de crença, o controle de um indivíduo por um ser maligno ou sobrenatural. Disponível em: <https://www.google.com/search? q=possess\%C3\%A3o\&rlz=1C1GCEA_enBR8 66BR866\&oq=possess\%C3\%A3o\&aqs=chrome..69i57j015.1619j0j7\&sourceid=chrom e\&ie=UTF-8>.

5 Exclusão social: neologismo, denota processo caracterizado pelo afastamento das pessoas de todas as instâncias da vida social. 
na existência assoprada a crença e êxtase, alicerces da alma que resiste à alienação ou possessão capitalista.

O espírito do homem pode alcançar a liberdade a partir da fé, álibi numinoso a despertar a consciência social pelo viés da religiosidade. Se a ordem de Deus é eterna e imutável, para Marx (2002, p. 9), “diante da impossibilidade de desvincular o homem de seu contexto, é preciso salientar que o homem atual atravessa uma fase de transição histórica, em que todos os valores são questionados, delineando-se uma perspectiva de reencontro do homem no homem".

A luta pela sobrevivência, por parte do trabalhador, passa por direitos, normativas, embate de classes em meio à sociedade do espetáculo, ou loucura moderna, realidade social estampada no êxtase do consumo fetichista. "Como um distúrbio psíquico e cultural, a loucura é uma doença. Ela não é uma doença qualquer, mas uma doença que atinge o 'espírito humano'. E aí se pode perceber o que escapa a essa visão sociológica" (PEREIRA, 1984, p. 34, apud LEITE, 2014, p. 331).

As desigualdades socioeconômica, jurídico-política e cultural culminam no encarceramento de sujeitos condenados pelo sistema jurídico-penal que rege relações sociais modernas, julga as mazelas da exclusão social expressas na violência, estigma e alienação dos condenados ao encarceramento. A manchete midiática "prisão versus fé" dá relevância à crença enquanto estruturante coletiva a salvar o sujeito alienado na prisão. Se o medo, a necessidade e temor da extinção levam a humanidade a agarrar às afirmações dos mitos e suas tradições, estas a arrastaram, com sua lógica ou palavreado, a erros e limitações, exclusões e guerras. E a causa desse impacto profundo que sofreram é revelada no testemunho visível no depoimento do astronauta Gene Cernan:

Eu fui o último homem a pisar na Lua em dezembro de 1972. Da superficie lunar olhava com temor reverencial para a Terra num transfundo azul muito escuro. O que eu via era demasiadamente belo para ser captado, demasiadamente lógico, cheio de propósito para ser fruto de um mero acidente cósmico. A gente se sentia interiormente obrigado a louvar a Deus. Deus deve existir por ter criado aquilo que eu tinha o privilégio de contemplar (BOFF, 2005, p. 67).

O conceito da crença é construção simbólica permeada por relações antropológicas. Essas, retratam a questão social que engloba a cultura e moral da sociedade envolta na alta modernidade. Esse fenômeno esconde 
sob o véu e grades da ética burguesa os sujeitos "incapazes" em alcançar a distribuição da riqueza socialmente produzida, mazela social retratada na riqueza e pobreza extremadas. Daí, é perfeitamente passível ir-se do santo e diabo, visto que

"num mercado divino" aonde "o espetáculo deslocou do grande 'Sujeito', que era necessário celebrar aos pequenos sujeitos que celebram a realização de sua apetência. [...] espetáculo em sua forma publicitária, que ocorre em todo lugar, tanto nas paredes da cidade e na grande imprensa quanto em casa, na televisão. [...] caímos das nuvens; na verdade, caímos do Altíssimo para a mercadoria (parece que cada época se dá os simulacros que merece) (MOREIRA; LEMOS; QUADROS, 2014, p. 14).

A coação das mais diversas formas corporais, em regime de reclusão, submetidas ao sistema prisional, alcança diferentes culturas e seus simbolismos. A exclusão determinada fere os Direitos Humanos expostos na Declaração Universal dos Direitos Humanos em seu Artigo (UNIC-Rio, 2009, p. 4) 1: "Todos os seres humanos nascem livres e iguais em dignidades e direitos. Dotado de razão e de consciência, devem agir uns para com os outros em espírito de fraternidade". A realidade do encarceramento retrata o trabalhador alienado ao "mundo do crime", induzido à miséria da razão, deformada e deformante, burocratizada.

A investigação dos conceitos fé e transe, mercado e sistema jurídico-penal, tal qual a possessão moderna, determinada historicamente, é ferramenta racional-filosófica. O transe molda as raias da alienação e libertação, reeducação e ressocialização, projeta a crença como norte para a libertação da situação de exclusão social. A massa da população encarcerada a superlotar presídios bebe da intolerância e dureza a contrapor a verdade, liberdade, criação. As religiões, ao falar de "outra dimensão", sagrada, utilizam os mitos vigentes nas sociedades, apropriam das grandes tradições. $\mathrm{Na} 22^{\mathrm{a}}$ reunião do Plenário da Assembleia Geral das Organizações das Nações Unidas (ONU), em 21 de outubro de 2003, em relato à mídia mundializada, o relato:

pela segunda vez em muitos meses, em seguida à omissão do Conselho de Segurança em agir, uma sessão de emergência da Assembleia Geral aprovou esmagadoramente uma medida acerca da situação no Oriente Médio - neste caso, exigindo que Israel interrompesse e revogasse a construção do muro que está sendo construído na Margem Ocidental (ONU, 2006, p. 11). 
Algumas crenças expressam sua linguagem mítica submetida a exclusivismos, intolerâncias, fixismos, passividade, submissão, ausência de espírito criativo e indagador. Em ebulição, as alas e celas da prisão beiram a convulsão social, expressão social estampada no paradigma da fé amalgamada à realidade concreta que expõe a loucura da estrutura dividida entre esses fenômenos adicionados ao transe, êxtase e possessão, além da fé cega, que alivia.

No âmbito da saúde mental, por exemplo, alguns autores manifestam uma visão negativa da religiosidade, como a concepção psicanalítica que considera a "atitude religiosa uma patologia ou transtorno neurótico (FREUD, 1927, p. 57 apud SIGNATES, 2016, p. 4). Na modernidade, o êxtase é sintoma da fé contemporânea, capenga dos olhos e sedenta por salvação, a beber do transe que pode elevar os homens a um patamar acima da (des) razão tomada pelo fenômeno da possessão de almas perdidas ou excluídas do sistema capitalista voraz e selvagem.

\section{Considerações finais}

A tarefa de analisar, pela epistemologia do transe, do êxtase e da possessão a religião e os excluídos na Contemporaneidade tem relação paradigmática de lastro histórico-espiritual com a fé como força abstrata, quiçá alienação, a moldar, determinar a consciência da população enclausurada.

A possessão mantém anestesiada a massa carcerária pelo viés da crença na salvação. Com relação aos excluídos instalados no cárcere da era pós, com base em diferenciados autores e matrizes ideológicas, retratam serem sujeitos sociais alijados do mercado de trabalho os quais equilibram no status social incapaz de superar ao karma ${ }^{6}$ físico, instalado na penumbra de sua luz espiritual.

A conclamar conceitos relacionados aos direitos, à emancipação, à libertação ao tempo que indaga sobre a questão penal a restringir, desde os primórdios, suas liberdades, o homem comum e pecador dá asas à imaginação enquanto ponte simbólica ao livramento, pelas raias da religião, do sistema diabólico retratado na prisão.

6 Karma - do sânscrito कऱम, transl. karma. Em páli, kamma, ambos os termos significam, literalmente, 'ação'. É um conceito de uso religioso dentro das doutrinas budista, hinduísta, jainista, sique e teosófica, em cada uma dessas doutrinas, o termo tem um sentido próprio. Disponível em: <https://pt.wikipedia.org/ wiki/Carma>. 
O campo religioso extravasa a si próprio pelo modo de como se reconhecem as religiões, da maneira como se produzem e consomem enquanto bens da salvação. Em concorrência, as mais diferenciadas instituições produzem o capital religioso, angariado na venda de um mesmo Deus, "em meio a concepções, magia, cosmologias, visões, revelações, transcendência e concepções do 'além"” (CAMURÇA, 2016). As religiões definem a si mesmas, umas às outras e os próprios sujeitos em êxtase na busca sem fim do transe numinoso.

Alienado à possessão dos espíritos, do capital da salvação, de leis paridas na necessidade de regulação da sociedade, de normativas que impõem o ajustamento moldado a alta modernidade, o transe coletivo toma o corpo em possessão como uma máquina plastificada, em êxtase, representada no corpo humano. A mente e alma são determinados e determinam o processo de individualização dos sujeitos em busca da salvação. Particularizada, a visão global do homem, pelas lentes da crença, o engendra na totalidade do sistema social em transe, êxtase e possessão.

\section{Referências}

BETTO, Frei. Cartas da prisão: 1969-1973. Rio de Janeiro: Agir, 2008. BÍBLIA DE ESTUDOS CONSELHEIRA. Barueri: Sociedade Bíblica do Brasil, 2019.

BOFF, Leonardo. Virtudes para um outro mundo possivel. Hospitalidade: direito e dever de todos. Petrópolis: Vozes, 2005.

BOURDIEU, Pierre. A economia das trocas simbólicas. Sérgio Miceli (org.). São Paulo: Perspectiva, 1974. p. 27-78.

CAMURÇA, Marcelo Ayres. Estilos de espiritualidade como critério para tipologias e interpretações do campo religioso na contemporaneidade. Porto Alegre, ano 18, n. 24, p. 18-32, jan-jul, 2016.

CASTEL, Roberto. As metamorfoses da questão social: uma crônica do salário. Petrópolis: Vozes, 1978.

COUTINHO, Carlos Nelson. O estruturalismo e a miséria da razão. São Paulo: Expressão Popular, 2010.

DECLARAÇÃO UNIVERSAL DOS DIREITOS HUMANOS. Rio de Janeiro: Centro de Informação das Nações Unidas para o Brasil - Unic Rio, 05 ago. 2009. 
DICIONÁRIO HOUAISS. Instituto Antônio Houaiss de Lexicografia e Bancos de Dados da Língua Portuguesa SC Ltda. Rio de Janeiro: Objetiva, 2008.

FERREIRA, Joel. A e SILVA, Valmor da. Paulo Missionário. Belo Horizonte: O lutador, 2009.

FOUCAULT, Michel. Vigiar e punir. 5. ed. Petrópolis: Vozes, 2010.

GIDDENS, Anthony. Política, sociologia e teoria social. São Paulo: Unesp, 2011.

LEITE, Fabiano Aparecido Costa. Quando o sagrado fala: O autor no discurso religioso. Reflexus, ano VIII, n. 12, 2014/2.

MARX, Karl. A Questão Judaica. São Paulo: Centauro, 2002.

. O Manifesto do Partido Comunista, Lisboa: Hugin, 1988.

MOREIRA, Alberto da S.; LEMOS, Carolina T.; QUADROS, Eduardo Gusmão de (Org.). A Religião entre o espetáculo e a intimidade. Goiânia: Ed. PUC Goiás, 2014.

ONU. ORGANIZAÇÕES DAS NAÇÕES UNIDAS. Palestina: a construção do muro. Brasil: Ed. ONU, 2006.

RUIZ, Castor M. M. Bartolomé. Os paradoxos do imaginário. Ensaio de Filosofia. São Leopoldo: Unisinos, 2004.

SIGNATES, Luiz. As curas espirituais como problema da ciência das religiões. VIII Congresso Internacional em Ciências da Religião PUC-Goiás, 28/04/2016.

SILVEIRA, Emerson. J. S. da. O Sagrado entre e além das Religiões: Um breve ensaio antropológico. Conferência no IV Congresso da ANPTECRE: O Futuro das Religiões no Brasil. 2013.

TADVALD, Marcelo. Corpo e Possessão na Teodiceia Racionalista do Espiritismo Kardecista. Ciências Sociais e Religião. Porto Alegre, ano 9, n. 9, p. 117-139, 2007. 